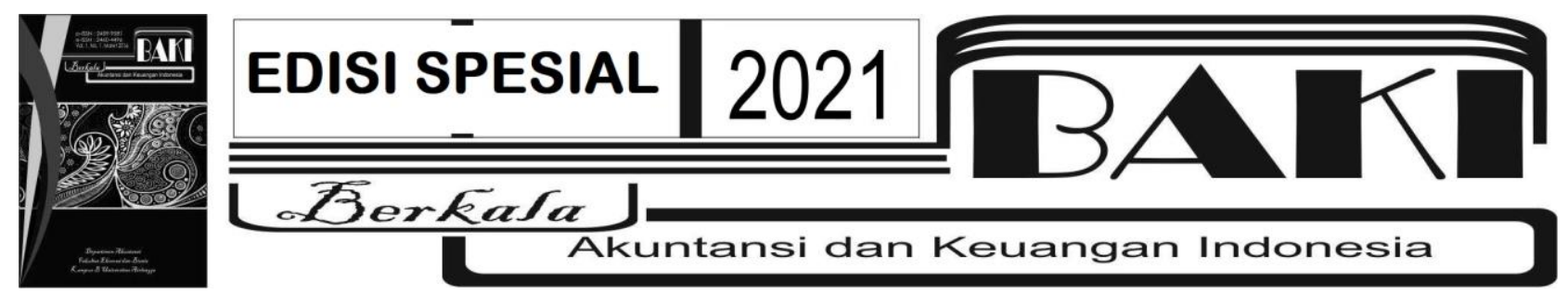

\title{
THE COVID-19 PANDEMIC: ITS IMPACT ON THE EXISTENCE OF BUSINESS ACTORS IN TRADITIONAL MARKETS
}

\section{PANDEMI COVID-19: DAMPAKNYA PADA EKSISTENSI PELAKU USAHA DI PASAR TRADISIONAL}

\author{
Syamsul $^{1 *}(\mathbb{D})$, Siti Masyita ${ }^{1}$
}

'STIE Panca Bhakti Palu

"corresponding author : syamsulsyahrir@gmail.com

INFOARTIKEL ABSTRACT

Histori Artikel:

Tanggal Masuk 15 Januari 2021

Revisi Diterima 17 Februari 2021

Tanggal Diterima 12 Juli 2021 Tersedia Online 31 Juli 2021

Keywords: COVID-19, Number of Buyers, Profit, Sales Turnover,

Kata Kunci: COVID-19, Laba, Omzet Penjualan, Jumlah Pembeli
Currently, the World is hit by the COVID-19 pandemic. The impact of this pandemic, is not only life threatening, but also has an economic downturn that is evenly distributed in almost all countries, including Indonesia. This study aims to determine and analyze the impact of the COVID-19 pandemic on the existence of business actors in traditional markets. The polls and samples of this study were chicken and egg traders at Manonda Central Market, Palu. Primary data was obtained through distributing questionnaires to research respondents. Based on the results of descriptive analysis and test one-way anova, it was found that there were differences in profit, sales turnover, and the number of buyers before and during the COVID-19 pandemic. This means that the COVID-19 pandemic threatens the existence of business actors in traditional markets. This research is useful for policy makers in maintaining the existence of business actors during the current COVID-19 pandemic.

\section{ABSTRAK}

Saat ini, Dunia dilanda pandemi COVID-19. Dampak dari pandemi ini, tidak hanya mengancam jiwa, akan tetapi juga berimbas pada keterpurukan ekonomi yang merata dihampir semua Negara, termasuk Indonesia. Penelitian ini bertujuan mengetahui dan menganalisis dampak pandemi COVID-19 terhadap eksistensi pelaku usaha di pasar tradisional. Populasi dan sampel penelitian ini adalah pedagang ayam dan telur di Pasar Sentral Manonda Palu. Data primer diperoleh melalui penyebaran kuisioner kepada responden penelitian. Berdasarkan hasil analisis deksriptif dan uji one-way anova, ditemukan bahwa terdapat perbedaan laba, omzet penjualan, dan jumlah pembeli sebelum dan selama pandemi COVID-19. Artinya, pandemi COVID-19 ini mengancam eksistensi pelaku usaha di pasar tradisional. Penelitian ini bermanfaat bagi pengambil kebijakan dalam mempertahankan eksistensi 
pelaku usaha pada masa pandemi COVID-19 sekarang ini.

Berkala Akuntansi dan Keuangan Indonesia p-ISSN: 2459-9581; e-ISSN 2460-4496 DOI: 10.20473/baki.v6ix.24681

Open access under Creative Common Attribution-Non Commercial-Share A like 4.0 International Licence (CC-BY-NC-SA)@(1) @()

\section{Pendahuluan}

Saat ini, Dunia dilanda pandemi COVID-19. Dampak dari pandemi ini, tidak hanya mengancam jiwa, tetapi juga berimbas pada keterpurukan ekonomi yang merata dihampir semua Negara. Di Indonesia, kondisi ini tercermin dari beberapa hasil penelitian. Misalnya, Dito, Erlina, \& Muda (2020) menunjukkan bahwa pandemi COVID-19 berdampak pada rendahnya sentimen investor terhadap pasar yang berimplikasi pada arah pasar yang cenderung negatif. Junaedi \& Salistia (2020) menginformasikan bahwa kondisi pandemi COVID-19 dan kebijakan social distancing memiliki pengaruh pada pasar modal di Indonesia. Saraswati (2020) juga menunjukkan terjadinya penurunan harga saham di semua sektor industri. Thaha (2020) dalam survei awalnya memprediksi bahwa apabila pandemi ini terus merajalela lebih dari 50 persen UMKM akan mengalami kebangkrutan dalam beberapa bulan ke depan. Amri (2020) dan Rosita (2020) juga menginformasikan bahwa terjadi penurunan omzet UMKM semenjak muncul COVID-19. Artinya, pandemi COVID-19 ini sangat mengancam bisnis dan perekonomian di Indonesia.

Dalam konteks perekonomian daerah, di awal merebaknya COVID-19, sejumlah pemerintah daerah telah menutup pasar-pasar sentral di wilayahnya disebabkan beberapa pedagang yang terkorfirmasi terjangkit COVID-19. Meskipun, penutupan pasar dianggap tidak tepat oleh kementrian perdagangan, karena keputusan itu akan memperburuk perekonomian masyarakat kelas bawah dan akan memukul para pedagang pasar yang tidak dapat menjangkau wadah jual beli daring (BBC News Indonesia, 2020). Akan tetapi, kebijakan yang serupa juga ditempuh oleh Pemerintah Kota Palu. Mulai dari pemberlakuan kebijakan Pembatasan Sosial Berskala Besar (PSBB), kemudian penerapan new normal pada sejumlah pasar sentral di wilayahnya, termasuk di Pasar Sentral Manonda Palu.

Penelitian ini bertujuan untuk mengetahui dan menganalisis eksistensi pelaku usaha di Pasar Sentral Manonda Palu selama pandemi COVID-19. Eksistensi diukur melalui laba, omzet penjualan, dan jumlah pembeli yang diterima oleh pelaku usaha sebelum dan selama pandemi COVID-19. Melalui penelitian ini, diharapkan dapat ditunjukkan apakah terjadi perbedaan laba, omzet penjualan, dan jumlah pembeli sebelum dan selama pandemi COVID-19. Informasi ini penting bagi pengambil kebijakan untuk membentengi pelaku usaha dari ancaman serangan COVID-19, dan menjaga eksistensi pelaku usaha di pasar tradisional. 


\section{Tinjauan Pustaka}

\subsection{Corona Virus Disease 2019 (COVID-19)}

Dikutip dari laman Lembaga IImu Pengetahuan Indonesia (LIPI) yang menyebutkan bahwa kata "Corona " berasal dari bahasa latin yang artinya crown atau mahkota, ini sesuai dengan bentuk Coronavirus itu sendiri yang kalau dilihat dengan mikroskop nampak seperti mahkota (Utama, 2003). Coronavirus adalah virus yang berbentuk bulat dan berdiameter sekitar 100-120 nm. Virus ini pertama kali diisolasi pada tahun 1965, dari cairan hidung seorang anak yang menampakan gejala pilek (common cold). Coronavirus atau virus corona merupakan keluarga besar virus yang menyebabkan infeksi saluran pernapasan atas ringan hingga sedang, seperti penyakit flu. Sampai saat ini terdapat tujuh coronavirus (HCoVs) yang telah diidentifikasi, yaitu: HCoV-229E, HCoV-OC43, HCoV-NL63, HCoV-HKU1, SARS-COV, MERSCOV, dan COVID-19 atau Novel Coronavirus (Fadli, 2020).

\subsection{Pasar Tradisional}

Di dalam Peraturan Presiden Nomor 112 Tahun 2007 Tentang Penataan dan Pembinaan Pasar Tradisional, Pusat Perbelanjaan dan Toko Modern, disebutkan bahwa pasar tradisional adalah pasar yang dibangun dan dikelola oleh pemerintah pusat, pemerintah daerah, swasta, Badan Usaha Milik Negara (BUMN) dan Badan Usaha Milik Daerah (BUMD), termasuk kerja sama dengan swasta dengan tempat usaha berupa toko, kios, los, dan tenda yang dimiliki/dikelola oleh pedagang kecil, pedagang menengah, swadaya masyarakat atau koperasi dengan usaha skala kecil, modal kecil dan dengan proses jual beli barang dagangan melalui tawar menawar. Intinya, ciri utama pasar tradisional adalah tempat bertemunya penjual dan pembeli secara langsung dan biasanya terdapat tawar menawar untuk menentapkan harga yang dipakati bersama sebelum jual beli terjadi.

\subsection{Eksistensi Pelaku Usaha}

Eksistensi pelaku usaha adalah strategi pelaku usaha dalam menjaga dan mempertahankan usahanya untuk tetap ada dan beroperasi secara terus menerus. Penelitian Wyati, Ariefiantoro, \& Santoso (2011) mengukur eksistensi usaha dengan melihat jumlah omzet penjualan, jumlah jam buka usaha, perputaran barang dagangan, biaya usaha, laba, dan laba bersih. Penelitian Wibawa, Priyagus, \& Gaffar (2018) eksistensi usaha diproksikan dengan jumlah omzet penjualan dan jam kerja. Sementara itu, pada penelitian ini eksistensi pelaku usaha diukur dengan menggunakan tiga variabel yaitu jumlah laba, omzet penjualan, dan jumlah pembeli.

\subsection{Pengembangan Hipotesis}


Penelitian Amri (2020) bertujuan untuk mengetahui dan menganalisis dampak pandemi virus corona terhadap UMKM yang ada di Indonesia. Metode analisis yang digunakan adalah metode deskriptif kualitatif. Hasilnya, menunjukkan terjadi penurunan omzet pelaku UMKM dan koperasi akibat covid-19 yang sangat signifikan sejak keberadaanya di akhir tahun 2019. Demikian pula, penelitian Rosita (2020) yang menganalisis sejauh mana pengaruh pandemi covid-19 terhadap UMKM di Indonesia. Penelitian tersebut menggunakan metode deskriptif kualitatif, dengan sumber data sekunder dari hasil penelitian, referensi dan berita online. Hasilnya, menunjukkan bahwa sejak merebaknya virus corona menyebabkan terjadinya penurunan omzet pelaku UMKM yang sangat signifikan. Terdapat beberapa lapangan usaha UMKM yang terkena dampak yang paling besar yaitu penyedia akomodasi, pariwisata, dan makan minum, perdagangan besar dan eceran, serta reparasi sepeda motor dan transportasi dan perdagangan. Sederhananya, hasil penelitian sebelumnya menunjukkan terjadinya penurunan omzet UMKM di masa pandemi COVID-19. Penurunan omzet, tentunya secara langsung berdampak pada perubahan laba UMKM di masa pandemi COVID-19 ini. Dengan demikian, hipotesis 1 yang diajukan pada penelitian ini adalah:

\section{$\mathrm{H}_{1}$ : Terdapat perbedaan laba yang diterima oleh pelaku usaha di pasar tradisional sebelum dan selama pandemi COVID-19}

Penelitian Soetjipto (2020) yang mengambil sampel pada 12 daerah di Propinsi Jawa Timur dengan mengumpulkan data dari 52 sampling secara insidental. Seluruh sampel tersebut adalah para pelaku usaha sektor UMKM yang masih beroperasi di tengah krisis pandemi COVID-19. Temuannya, memberitakan bahwa akibat dari pandemi COVID-19 hampir semua pelaku usaha di sektor UMKM mengalami penurunan omzet penjualan yang sangat drastis, mengalami berbagai kendala pemasaran dan penjualan, termasuk penyaluran produk. Begitu pula, penelitian Hardilawati (2020) yang menemukan bahwa mayoritas UMKM merasakan penurunan omzet selama adanya COVID-19. Singkatnya, hasil riset tersebut menginformasikan bahwa terdapat penurunan omzet penjualan UMKM di masa pandemi COVID-19. Oleh Karena itu, hipotesis 2 yang disusun pada penelitian ini adalah:

\section{$\mathrm{H}_{2}$ : Terdapat perbedaan omzet penjualan yang diterima oleh pelaku usaha di pasar tradisional sebelum dan selama pandemi COVID-19}

Berdasarkan hasil penelitiannya Hardilawati (2020) mengungkapkan bahwa salah satu penyebab terjadinya penurunan omzet penjualan UMKM di masa pandemi COVID-19, karena berkurangnya aktivitas masyarakat yang dilakukan di luar rumah. Kondisi ini terjadi, karena sebagian masyarakat khawatir akan tertular virus corona, apabila mereka berada di luar rumah atau di tempat keramaian. Lebih dari itu, beredarnya himbauan maupun kebijakan dari pemerintah untuk berdiam diri di rumah masing-masing turut memaksa sebagian masyarakat lebih memilih melakukan pembelian online. Dalam konteks penelitian ini, munculnya pandemi 
COVID-19 mengakibatkan pembeli yang berkunjung ke pasar tradisional menjadi berkurang (sedikit). Oleh karena itu, hipotesis 3 penelitian ini dirumuskan sebagai berikut:

\section{$\mathrm{H}_{3}$ : Terdapat perbedaan jumlah pembeli yang diterima oleh pelaku usaha di pasar tradisional sebelum dan selama pandemi COVID-19}

\section{Metodologi Penelitian}

\subsection{Jenis Penelitian}

Penelitian ini adalah jenis penelitian kuantitatif yang bertujuan menjelaskan dampak pandemi COVID-19 terhadap eksistensi pelaku usaha di pasar tradisional.

\subsection{Jenis dan Sumber Data}

Jenis data yang digunakan dalam penelitian ini adalah kuantitatif. Data kuantitatif penelitian ini terdiri dari besarnya laba, omzet penjualan dan jumlah pembeli. Data primer tersebut diperoleh melalui penyebaran kuisioner terbuka kepada pelaku usaha yang menjadi sampel penelitian ini. Untuk mengetahui besarnya laba, omzet penjualan, dan jumlah pembeli, di dalam kuisioner tersebut dibagi ke dalam tiga bagian pertanyaan. Bentuk pendahuluan terkait dengan identitas responden. Bagian utama pada kuisioner tersebut berisi pertanyaan tentang rerata perbulan besarnya laba, omzet penjualan, dan jumlah pembeli yang diterima oleh pelaku usaha sebelum dan pada saat pandemi COVID-19. Bagian pelengkap, terkait dengan pertanyaan besarnya persentase perubahan laba, omzet penjualan di masa pandemi COVID19. Bagian pelengkap ini, dimasukkan untuk melengkapi bagian utama kuisioner, apabila terdapat pelaku usaha yang bingung menetapkan (memperkirakan) rerata laba, omzet penjualan, dan jumlah pembeli per bulan yang mereka terima selama pandemi COVID-19 (lihat lampiran). Kuisioner tersebut dibagikan kepada responden pada bulan Oktober Tahun 2020.

\subsection{Populasi, Sampel, dan Tehnik Penarikan Sampel}

Populasi penelitian yaitu pedagang ayam potong dan telur di Pasar Sentral Manonda Palu. Menurut Kepala Kantor Dinas Perdagangan dan Perindustrian, sebanyak 31 pedagang ayam potong dan telur di pasar sentral manonda palu yang terdaftar di kantor Dinas Perdagangan dan Perindustrian. Metode pengambilan sampel menggunakan teknik sampling jenuh. Oleh karena itu, sampel penelitian ini sebanyak 31 orang (pelaku usaha). Penelitian ini hanya berfokus pada pedagang ayam potong dan telur sebagai sampel penelitian, didasarkan pada pertimbangan bahwa pedagang ayam potong dan telur merupakan salah satu sub sektor usaha yang paling merasakan dampak dari pandemi COVID-19, apalagi dimasa penerapan kebijakan PSBB. Kenapa demikian, karena pada saat itu, permintaan pasar turun drastis akibat banyaknya sektor ekonomi seperti hotel, restoran, usaha catering dan pengolahan daging ayam dan telur lainnya yang tidak beroperasi. Padahal, dari sumber itulah pembeli utama dari 
pedagang ayam dan telur. Kemudian, dari segi pembeli rumah tangga selain karena takut tertular Virus Corona. Diberlakunnya PSBB pada saat itu, membuat seseorang (calon pembeli) memilih untuk berdiam diri dirumah, menghindari keramaian sesuai dengan anjuran pemerintah. Sehingga, kondisi ini tentunya berdampak pada sepinya pengungjung di pasar tradisional dan pada akhirnya berimplikasi pula pada eksistensi pedagang ayam dan telur.

\subsection{Definisi Operasional variabel}

Pada penelitian ini, eksistensi pelaku usaha adalah kemampuan pelaku usaha untuk bertahan di tengah pandemic COVID-19. Eksistensi ini diukur berdasarkan besarnya laba, omzet penjualan, dan jumlah pembeli sebelum dan selama pandemic COVID-19. Laba adalah keuntungan/laba bruto (penjualan dikurangi beban pokok penjualan/modal) yang didapatkan pelaku usaha sebelum dan selama pandemic COVID-19, yang dinyatakan dalam satuan rupiah. Omset penjualan adalah total penjualan yang diterima sebelum dan ditengah pandemi COVID19 , yang dinyatakan dalam satuan rupiah. Sementara itu, jumlah pembeli adalah jumlah orang yang berbelanja (bertransaksi) di tempat pelaku usaha sebelum dan selama pandemi COVID19 , yang dinyatakan dalam satuan orang.

Pengukuran variabel laba, omzet penjualan, dan jumlah pembeli sebelum COVID-19, yaitu berdasarkan jawaban yang diberikan oleh pelaku usaha tentang rerata laba, omzet penjualan, dan jumlah pembeli per bulan yang mereka dapatkan sebelum Pandemi COVID-19. Kemudian, pengukuran variabel laba, omzet penjualan, dan jumlah pembeli selama COVID-19 pada saat dilaksanakannya kebijakan PSBB adalah berdasarkan jawaban yang diberikan oleh pelaku usaha terkait rerata laba, omzet penjualan, dan jumlah pembeli perbulan yang diterima selama penerapakan kebijakan PSBB (bulan April, Mei, dan Juni) di masa pandemi COVID-19. Begitupula, variabel laba, omzet penjualan, dan jumlah pembeli selama COVID-19 pada saat diberlakukannya kebijakan new normal diukur berdasarkan jawaban yang diberikan oleh pelaku usaha terkait rerata laba, omzet penjualan, dan jumlah pembeli perbulan yang mereka peroleh pada saat pemberlakuan kebijakan new normal (bulan Juli, Agustus, dan September) di masa Pandemi COVID-19. Lebih lanjut, dapat dilihat pada tabel 1 di bawah ini.

Tabel 1. Pengukuran Variabel

\begin{tabular}{|c|c|c|c|}
\hline \multirow{2}{*}{ Eksistensi Pelaku Usaha } & \multirow{2}{*}{$\begin{array}{l}\text { Sebelum } \\
\text { COVID-19 }\end{array}$} & \multicolumn{2}{|c|}{ Pandemi COVID-19 } \\
\hline & & PSBB & New Normal \\
\hline $\begin{array}{l}\text { Laba (Rp) } \\
\text { Penjualan (Rp) } \\
\text { Jumlah Pembeli (Org) }\end{array}$ & $\begin{array}{l}\text { Sebelum Bulan Maret } \\
2020\end{array}$ & $\begin{array}{l}\text { Bulan April, } \\
\text { Mei, dan } \\
\text { Juni }\end{array}$ & $\begin{array}{l}\text { Bulan Juli, } \\
\text { Agustus, dan } \\
\text { September }\end{array}$ \\
\hline
\end{tabular}

\subsection{Teknik Analisis Data}


Penelitian ini menggunakan teknik analisis deskriptif dan kuantitatif. Analisis deskriptif dimaksudkan untuk menganalisis perubahan laba, omzet penjualan, dan jumlah pembeli yang diterima pelaku usaha sebelum dan selama (PSBB dan new normal) pandemi COVID-19. Analisis kuantitatif dilakukan melalui uji one-way anova yang bertujuan untuk menguji perbedaan rata-rata laba, omzet penjualan, dan jumlah pembeli yang diterima pelaku usaha antara sebelum, saat pandemi dan new normal. Namun, sebelum dilakukan pengujian tersebut, terlebih dahulu dilakukan uji normalitas sebaran dan homogenitas. Perbedaan rerata dengan uji one-way anova melalui program SPSS yang diformulasikan sebagai berikut :

$$
F=\frac{R J K_{a}}{R J K_{i}}
$$

Keterangan :

$R J K_{a}=$ Variansi antar kelompok (rerata jumlah kuadrat antar)

$R J K_{i}=$ Variansi kekeliruan pemilihan sampel (rerata jumlah kuadrat inter)

Dimana,

$$
\begin{gathered}
R J K_{a}=\frac{\sum_{j=1}^{k} J_{j^{2}} / n_{j}-J^{2} / N}{k-1} \\
R J K_{i}=\frac{\sum_{j=1}^{k} \sum_{i}^{n_{j}} X_{i j^{n}}-\sum_{j=1}^{k} J_{j^{n}} / n_{j}}{N-k}
\end{gathered}
$$

Dengan keterangan :

$\mathrm{J}=$ Jumlah seluruh data

$\mathrm{N}=$ Banyak data

$\mathrm{k}=$ Banyak kelompok

$\mathrm{n}_{\mathrm{j}}=$ Banyak anggota kelompok $-\mathrm{j}$

$\mathrm{J}_{\mathrm{j}}=$ Jumlah data dilakukan dalam kelompok $-\mathrm{j}$

\section{Hasil dan Pembahasan}

\subsection{Deskriptif Karakteristik Responden}

Pada tabel 2 dapat dijelaskan bahwa dari 31 orang responden terdapat 22 orang atau 71 persen pelaku usaha berjenis kelamin laki-laki, sedangkan 9 orang atau 32 persen berjenis kelamin perempuan. Artinya, pelaku usaha pedagang ayam potong dan telur didominasi kaum laki-laki.

Tabel 2. Deskripsi Reponden Berdasarkan Jenis Kelamin

\begin{tabular}{ccccc}
\hline No & Jenis Kelamin & Frequency & Percent & Cumulative Percent \\
\hline 1 & Laki-Laki & 22 & $71 \%$ & $71 \%$ \\
2 & Perempuan & 9 & $29 \%$ & $100 \%$ \\
Total & & 31 & $100 \%$ & \\
\hline
\end{tabular}


Sumber: Data primer, 2020

Tabel 3 dapat dilihat bahwa usia responden pelaku usaha di Pasar Sentral Manonda beragam. Meskipun, terlihat bahwa paling banyak adalah responden yang berumur $20-30$ tahun yaitu sebanyak 11 orang atau 35,5 persen. Hal ini terjadi karena di usia $20-30$ tahun sudah memiliki tanggung jawab salah satunya adalah menghidupi keluarga apalagi di dalam situasi COVID-19.

Tabel 3. Deskripsi Reponden Berdasarkan Umur

\begin{tabular}{rcccc}
\hline No & Usia & Frequency & Percent & Cumulative Percent \\
\hline 1 & Di bawah 20 Tahun & 2 & $6,50 \%$ & $6,50 \%$ \\
2 & 20 Sampai 30 Tahun & 11 & $35,50 \%$ & $41,90 \%$ \\
3 & 31 Sampai 40 Tahun & 10 & $32,30 \%$ & $74,20 \%$ \\
4 & 41 Sampai 50 Tahun & 8 & $25,80 \%$ & $100 \%$ \\
Total & & 31 & $100 \%$ & \\
\hline
\end{tabular}

Sumber: data primer, 2020

Berdasarkan tabel 4 dapat dikatakan bahwa sebagian besar responden mempunyai pengalaman berdagang selama 1 sampai 5 tahun sebanyak 15 orang atau sekitar 48,4 persen. Artinya, pedagang ayam potong dan telur di Pasar Manonda Palu masih didominasi oleh pelaku usaha mudah.

Tabel 4. Deskripsi Reponden Berdasarkan Pengalaman Berusaha

\begin{tabular}{ccccc}
\hline No & Pengalaman Berdagang & Frequency & Percent & $\begin{array}{c}\text { Cumulative } \\
\text { Percent }\end{array}$ \\
\hline 1 & 1 Sampai 5 Tahun & 15 & $48,40 \%$ & $48,40 \%$ \\
2 & 6 Sampai 10 Tahun & 7 & $22,60 \%$ & $71 \%$ \\
3 & 11 Sampai 15 Tahun & 7 & $22,60 \%$ & $93,50 \%$ \\
4 & 16 Sampai 20 Tahun & 2 & $6,50 \%$ & $100 \%$ \\
Total & & 31 & $100 \%$ & \\
\hline
\end{tabular}

Sumber: Data primer, 2020

\subsection{Analisis Deskriptif}

Pada tabel 5 terlihat, bahwa sebelum adanya pandemi COVID-19, pelaku usaha menerima laba paling sedikit sebesar Rp7.000.000,00 dan paling besar adalah Rp89.000.000,00 perbulan. Sedangkan, ditengah pandemi COVID-19 pada saat PSBB (bulan April, Mei, dan Juni) laba paling rendah sebesar Rp1.750.000,00 dan paling tinggi adalah Rp71.200.000,00 perbulan. Saat penerapan new normal (bulan Juli, Agustus, dan September) pelaku usaha memperoleh laba paling kecil sebesar Rp2.100.000,00 dan paling besar adalah Rp81.880.000,00 perbulan. Dengan rerata laba perbulan sebelum munculnya COVID-19 
sebesar Rp23.241.935,00. Kemudian, rerata Laba perbulan yang diterima ditengah pandemi COVID-19 saat PSBB sebesar Rp12.474.193,55 atau menurun sebesar Rp11.429.032,26. Rerata laba yang diperoleh saat diterapkan new normal sebesar Rp15.207.983,87 mengalami kenaikan sebesar Rp2.733.790,32, walaupun rerata laba yang diterima tersebut belum sama sebelum munculnya COVID-19. Singkatnya, terjadi penurunan laba yang diterima oleh pelaku usaha di pasar tradisional selama pandemi COVID-19.

Selanjutnya, omzet penjualan pada tabel 5 juga terlihat bahwa omzet penjualan tertinggi perbulan sebelum adanya pandemi COVID-19 sebesar Rp265.000.000,00, terendah sebesar Rp20.000.000,00 dengan rerata omzet penjualan sebesar Rp91.774.193,55. Namun demikian, pada saat tersebarnya COVID-19 dan diterapkannya PSBB, terlihat bahwa omzet penjualan tertinggi sebesar Rp150.000.000,00, dan terendah Rp7.500.000,00. Dengan rerata omzet penjualan pada saat diberlakukannya PSBB sebesar Rp46.908.064,52, ini berarti mengalami penurunan omzet penjualan sebesar Rp44.866.129,03. Kemudian, omzet penjualan perbulan pada saat diterapkannya new normal terendah sebesar Rp8.625.000,00 dan tertinggi sebesar Rp165.000.000,00, dengan rerata omzet penjualan sebesar Rp56,934.354,84. Dengan kata lain, bahwa pada saat penerapan new normal secara rerata pelaku usaha mengalami peningkatan omzet penjualan sebesar Rp10.026.290,32, meskipun belum mencapai rerata omzet penjualan sebelum merebaknya pandemi COVID-19.

Tabel 5. Eksistensi Pelaku Usaha Sebelum dan Saat COVID-19 (Rerata Perbulan)

\begin{tabular}{lrrrr}
\hline & Rerata/Bulan & Terendah/Bulan & Tertinggi/Bulan & N \\
\hline Laba & & & & \\
Sebelum COVID-19 & $23,903,225.81$ & $7,000,000.00$ & $89,000,000.00$ & 31 \\
PSBB & $12,474,193.55$ & $1,750,000.00$ & $71,200,000.00$ & 31 \\
New Normal & $15,207,983.87$ & $2,100,000.00$ & $81,880,000.00$ & 31 \\
\hline Penjualan & & & & \\
Sebelum COVID-19 & $91,774,193.55$ & $20,000,000.00$ & $265,000,000.00$ & 31 \\
PSBB & $46,908,064.52$ & $7,500,000.00$ & $150,000,000.00$ & 31 \\
New Normal & $56,934,354.84$ & $8,625,000.00$ & $165,000,000.00$ & 31 \\
\hline Jumlah Pembeli & & & & \\
Sebelum COVID-19 & 336 & 100 & 600 & 31 \\
PSBB & 169 & 33 & 400 & 31 \\
New Normal & 207 & 49 & 460 & 31 \\
\hline
\end{tabular}

Sumber: Data Primer, 2020

Berikutnya, dilihat dari jumlah pembeli pada tabel 5 tertera bahwa jumlah pembeli tertinggi sebelum COVID-19 yaitu sebanyak 600 orang per bulan, dan terendah sebanyak 100 orang per 
bulan, dengan rerata jumlah pembeli sebanyak 336 orang. Kemudian, pada saat terjadinya pandemi COVID-19 dengan diterapkannya PSBB, terlihat bahwa angka pembeli tertinggi sebanyak 400 orang, dan terendah sebanyak 33 orang per bulan. Dengan rerata jumlah pembeli sejak diterapkannya PSBB yaitu 160 orang, artinya terjadi penurunan jumlah pembeli sebanyak 167 orang per bulan. Lebih lanjut, pada saat diterapkannya new normal, jumlah pembeli tertinggi sebanyak 460 orang, terendah 49 orang per bulan, dengan rerata jumlah pembeli sebanyak 207 per bulan. Angka rerata ini menandakan bahwa terjadi peningkatan jumlah pembeli 38 orang perbulan pada saat perubahan status dari PSBB ke pemberlakuan new normal. Dengan demikian, berdasarkan hasil survei yang tercermin pada tabel 4 tersebut, dapat dikatakan bahwa terjadi penurunan laba, omzet penjualan dan jumlah pembeli semenjak adanya COVID-19 khsusunya pada saat diberlakukannya PSBB. Dengan kata lain, bahwa eksistensi pelaku usaha di pasar tradisional, khususnya pelaku usaha di Pasar Manonda Palu terancam semencak merebaknya COVID-19 utamanya pada saat diterapkannya kebijakan PSBB oleh pemerintah.

Salah satu penyebab naiknya laba, omzet penjualan, dan jumlah pembeli pada waktu penerapan new normal adalah kembalinya beroperasi usaha-usaha pengelolaan daging ayam dan telur. Misalnya, dibukanya kembali hotel-hotel, dan restoran/rumah makan, dan catering. Selain itu, kegiatan/acara sosial masyarakat yang mengumpulkan orang banyak (menciptakan kerumunan) itu dilarang pada saat PSBB, sudah diperbolehkan kembali di era new normal dengan tetap mematuhi protokol kesehatan. Pelonggaran aktifitas masyarakat di era new normal dan diperbolehkannya kembali sumber-sumber ekonomi tersebut, meskipun operasinya masih dibatasi, baik dari jam operasional maupun pembatasan kapasitas orang dalam setiap tempat kegiatan. Akan tetapi, setidaknya mulai memicu kenaikan permintaan kebutuhan daging ayam dan telur, untuk diolah dan dikonsumsi pada kegiatan-kegiatan tersebut. Oleh karena itu, permitaan dari sumber ekonomi tersebut, memang masih belum optimal, seperti sebelum adanya COVID-19. Sehingga, kondisi juga berimplikasi pada laba, omzet penjualan, dan jumlah pembeli yang belum maksimal pula yang diterima oleh pelaku usaha di pasar tradisional. Intinya, aktivitas-aktivitas yang melibatkan orang banyak pada saat penerapan PSBB semua itu dilarang, sehingga sumber-sumber ekonomi usaha pengolahan daging ayam dan telur tidak beroperasi, yang berimplikasi pada penurunan permintaan daging ayam dan telur. Sementara itu, di era new normal aktivitas tersebut diperbolehkan dengan tetap menjaga protokoler kesehatan, sehingga sumber-sumber ekonomi pun mulai beroperasi, dan pasar tradisional yang tadinya sepi pengunjung berangsur-angsur mulai ramai. Akhirnya, eksistensi pelaku usaha di pasar tradisional perlahan-lahan mulai menguat kembali.

\subsection{Uji One-Way Anova}


Meskipun, secara matematis melalui analisis deskriptif terlihat adanya perbedaan antara laba, penjualan, dan jumlah pembeli yang terima pelaku usaha sebelum dan selama pandemi COVID-19. Akan tetapi, secara statisitk belum tentu terdapat perbedaan yang signifikan. Oleh karena itu, dilakukan pengujian statistik dengan menggunakan one-way anova. Hasilnya, pada tabel 6, terlihat bahwa nilai F-hitung untuk variabel laba sebesar 7,977 dengan taraf signifikansi sebesar 0,006 lebih rendah dari 0,05. Artinya, bahwa terdapat perbedaan laba yang diterima oleh pelaku usaha sebelum dan setelah pandemi COVID-19. Nilai F-hitung untuk varibel penjualan sebesar 7,061 dengan tingkat signifikansi sebesar 0,01 lebih rendah dari tingkat signifikannya yang ditetapkan sebesar 0,05. Angka ini mengindikasikan pula bahwa terdapat perbedaan omzet penjualan yang didapatkan oleh pelaku usaha sebelum dan setelah pandemi COVID-19. Kemudian, variabel jumlah pembeli mempunyai nilai F-hitung sebesar 25,566 dengan kadar signifikansi sebesar $0,000<0,05$. Hal ini berarti, ada perbedaan jumlah pembeli yang diterima oleh pelaku usaha sebelum dan setelah pandemi COVID-19.

Tabel 6. Hasil Uji One-Way Anova Eksistensi Pelaku Usaha Sebelum dan Setelah COVID-19

\begin{tabular}{|c|c|c|c|c|c|c|}
\hline \multirow{2}{*}{ Variabel } & \multicolumn{4}{|c|}{ Sum of } & \multirow[b]{2}{*}{$\mathrm{F}$} & \multirow[b]{2}{*}{ Sig. } \\
\hline & & Squares & Df & Mean Square & & \\
\hline \multirow{5}{*}{ Laba } & Between & 156932234579 & & 115693223457 & 7.977 & .006 \\
\hline & Groups & 1330.000 & & 91330.000 & & \\
\hline & Within & 118032805484 & & 6019672134247 & & \\
\hline & Groups & 87900.000 & & 4798.000 & & \\
\hline & Total & $\begin{array}{r}133726028942 \\
79200.000\end{array}$ & & 61 & & \\
\hline \multirow{5}{*}{ Penjualan } & Between & 246180350130 & & 124618035013 & 7.061 & .010 \\
\hline & Groups & 04000.000 & & 004000.000 & & \\
\hline & Within & 209180971028 & & 6034863495171 & & \\
\hline & Groups & 226000.000 & & 37100.000 & & \\
\hline & Total & $\begin{array}{r}233799006041 \\
230000.000\end{array}$ & & 61 & & \\
\hline \multirow{5}{*}{ Jumlah Pembeli } & Between & 337148.129 & & 337148.129 & 26.566 & .000 \\
\hline & Groups & & & & & \\
\hline & Within & 761461.613 & & 12691.027 & & \\
\hline & Groups & & & & & \\
\hline & Total & 1098609.742 & & 61 & & \\
\hline
\end{tabular}

Sumber: hasil olahan SPSS, 2020

Selanjutnya, pada tabel 7 tertera hasil uji one-way anova terkait eksistensi pelaku usaha di tengah pandemi COVID-19, yaitu pada saat PSBB dan New Normal. Mengacu pada tabel tersebut, dapat disampaikan bahwa nilai F-hitung variabel laba sebesar 0,688 dengan tingkat 
signifikansi sebesar 0,410, lebih tinggi dari nilai signifikansi yang ditetapkan sebesar 0,05. Maknanya, secara statistik tidak terdapat perbedaan laba yang diterima oleh pelaku usaha pada saat PSBB dan new normal di masa pandemi COVID-19. Sementara itu, nilai F-hitung variabel omzet penjualan sebesar 0,881 dengan taraf signifikansi sebesar 0,352 lebih besar dari taraf signifikansi yang diajukan sebesar 0,05. Dengan demikian dapat dikatakan bahwa tidak terdapat perbedaan omzet penjualan yang diperoleh pelaku usaha baik pada saat PSBB maupun di masa new normal. Untuk variabel jumlah pembeli memiliki nilai F-hitung sebesar 2,539 dengan tingkat signifikansi sebesar 0,116 lebih tinggi dari 0,05. Artinya, tidak terdapat perbedaan jumlah pembeli yang diterima pelaku usaha pada saat PSBB dan new normal.

Tabel 7. Hasil Uji One-Way Anova

Eksistensi Pelaku Usaha Pada Saat PSBB dan New Normal

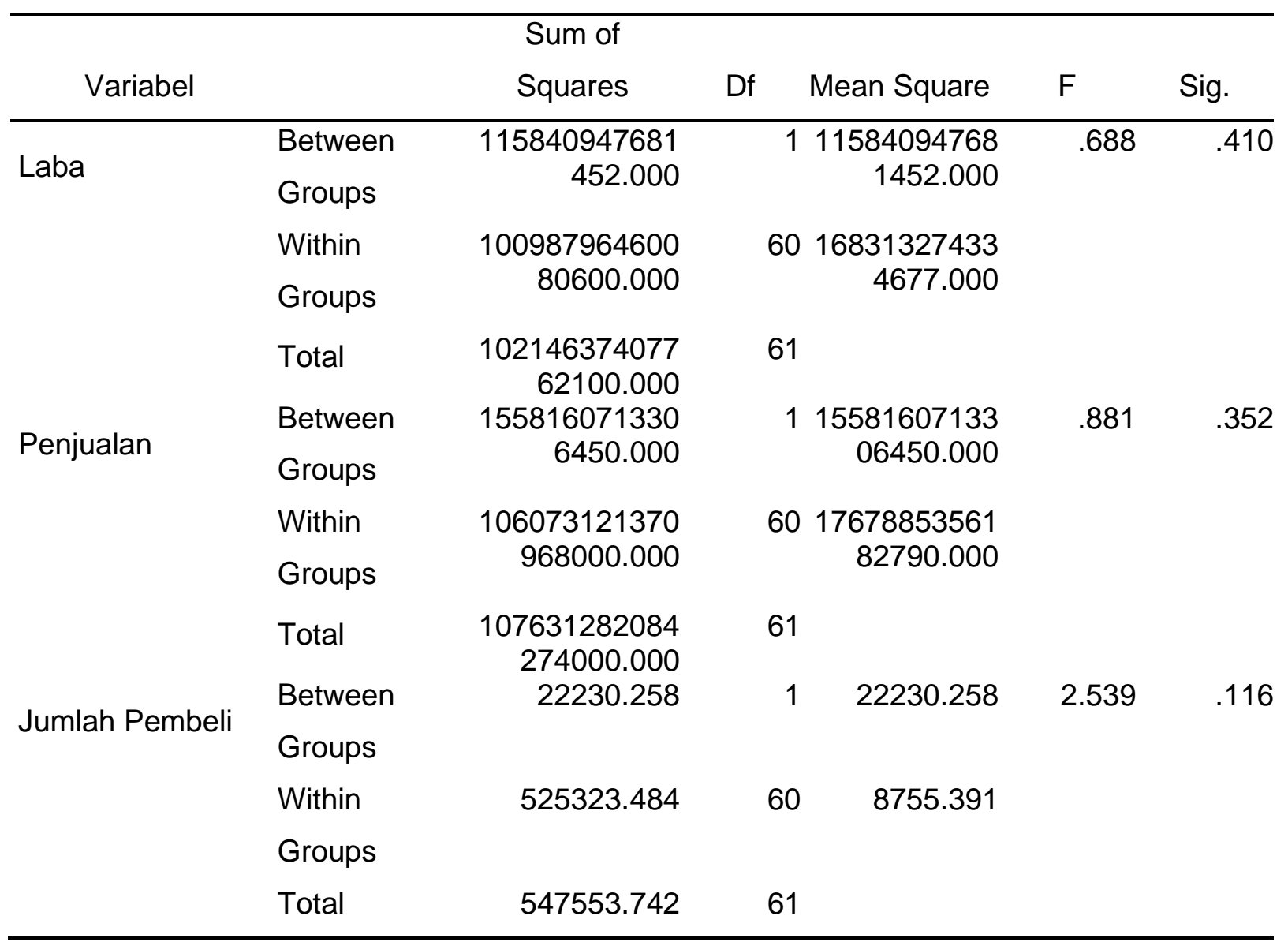

Sumber: hasil olahan SPSS, 2020

Selanjutnya, hasil analisis pada tabel 9 menunjukkan variabel laba memiliki nilai F-hitung 5,880 dengan tingkat signifikansi sebesar 0,004 $<0,05$. Artinya, terdapat perbedaan laba yang diperoleh pelaku usaha sebelum dan selama pandemi COVID-19. Oleh karena itu, hipotesis 1 dinyatakan terdukung. Begitupula, nilai F-hitung variabel omzet penjualan sebesar 5,879 dengan signifikansi sebesar 0,004 < 0,05. Angka ini menunjukkan terdapat perbedaan omzet penjualan yang diterima pelaku usaha sebelum dan pada saat pandemi COVID-19, sehingga hipotesis 2 terdukung. Terakhir, nilai F-hitung variabel jumlah pembeli sebesar 20,658 dengan 
signifikansi sebesar 0,00 $<0,05$, sehingga dapat dikatakan bahwa terdapat perbedaan jumlah pembeli pada pelaku usaha sebelum dan ditengah pandemi COVID-19. Dengan demikian, hipotesis 3 yang ajukan dinyatakan diterima.

Tabel 8. Hasil Uji One-Way Anova

Eksistensi Pelaku Usaha Sebelum COVID-19, PSBB, dan New Normal

\begin{tabular}{|c|c|c|c|c|c|c|}
\hline Variabel & & $\begin{array}{l}\text { Sum of } \\
\text { Squares }\end{array}$ & Df & Mean Square & $\mathrm{F}$ & Sig. \\
\hline \multirow{6}{*}{ Laba } & Between & 22082707420 & \multirow{2}{*}{2} & 1104135371 & \multirow{2}{*}{5,880} & \multirow{2}{*}{,004 } \\
\hline & Groups & 69891,000 & & 034945,000 & & \\
\hline & Within & 16899506137 & \multirow{2}{*}{90} & 1877722904 & & \\
\hline & Groups & 500000,000 & & 16666,660 & & \\
\hline & & 19107776879 & \multirow{2}{*}{92} & & & \\
\hline & TOlal & 569888,000 & & & & \\
\hline \multirow{6}{*}{ Penjualan } & Between & 34382207397 & \multirow{2}{*}{2} & 1719110369 & \multirow{2}{*}{5,879} & \multirow{2}{*}{,004 } \\
\hline & Groups & 311828,000 & & 8655910,000 & & \\
\hline & Within & 26316054072 & \multirow{2}{*}{90} & 2924006008 & & \\
\hline & Groups & 5806400,000 & & 064515,000 & & \\
\hline & Total & 29754274812 & 92 & & & \\
\hline & TVlal & 3118210,000 & Jc & & & \\
\hline \multirow{4}{*}{ Jumlah Pembeli } & Between & 473335,634 & 2 & 236667,817 & \multirow{4}{*}{20,658} & \multirow{4}{*}{,000 } \\
\hline & Groups & & & & & \\
\hline & $\begin{array}{l}\text { Within } \\
\text { Groups }\end{array}$ & 1031078,323 & 90 & 11456,426 & & \\
\hline & Total & 1504413,957 & 92 & & & \\
\hline
\end{tabular}

Sumber: hasil olahan SPSS, 2020

\subsection{Pembahasan}

Eksistensi pelaku usaha pada pasar tradisional selama pandemi COVID-19. Dalam konteks penelitian ini, eksistensi pelaku usaha diukur berdasarkan jumlah laba, omzet penjualan, dan jumlah pembeli sebelum dan selama pandemi COVID-19. Melalui analisis deskriptif menunjukkan bahwa laba, omzet penjualan, dan jumlah pembeli yang diperoleh selama pandemi lebih rendah dibanding sebelum terjadi pandemi COVID-19. Adapun, selama pandemi COVID-19 laba, omzet penjualan, dan jumlah pembeli lebih tinggi pada saat diterapkannya kebijakan new normal daripada penerapan PSBB. Meskipun belum menyerupai laba, omzet penjualan, dan jumlah pembeli sebelum terjadi pandemi COVID-19. Artinya, terjadi 
kenaikan laba, omzet penjualan, dan jumlah pembeli pada saat penerapan kebijakan new normal, walaupun perubahan itu belum cukup berarti.

Studi ini menguji perbedaan laba, omzet penjualan, dan jumlah pembeli yang diterima pelaku usaha di pasar tradisional. Berdasarkan uji one-way anova, penelitian ini menunjukkan bahwa: Pertama, terdapat perbedaan laba, omzet penjualan, dan jumlah pembeli yang signifikan antara sebelum dan setelah pandemi COVID-19. Kedua, tidak terdapat perbedaan laba, omzet penjualan, dan jumlah pembeli yang signifikan antara penerapan PSBB dan new normal. Terakhir, terdapat perbedaan laba, omzet penjualan, dan jumlah pembeli yang signifikan antara sebelum dan ditengah pandemi COVID-19. Singkatnya, penelitian ini berhasil memberikan bukti baru bahwa pandemi COVID-19 mengancam eksistensi pelaku usaha di pasar tradisional.

Riset ini, secara khusus menunjukkan tidak adanya perbedaan laba, omzet penjualan, dan jumlah pembeli yang signifikan antara penerapan PSBB dan new normal. Tidak terdapatnya perbedaan tersebut, disebabkan masih rendahnya permintaan dari usaha pengolahan daging ayam dan telur, maupun sumber-sumber ekonomi lainnya di era new normal. Dengan kata lain, meskipun sumber-seperti ekonomi seperti hotel, restoran, café, warung makan, dan usaha catering sudah mulai beroperasi tetapi masih sangat terbatas. Misalnya, hotel dan restoran tidak boleh melebihi 50 persen kapasitas ruangan yang disediakan. Begitupula, kegiatan sosial masyarakat, seperti acara keagamaan, syukuran, perkawinan, dan aktivitas lain yang berpotensi menimbulkan masyarakat banyak, walapun sudah diperbolehkan namun tetap dijaga dan dibatasi. Sehingga, keadaan ini berimplikasi pada berkurangnya konsumsi daging ayam dan telur yang biasanya disediakan pada kegiatankegiatan tersebut. Disisi lain, rendahnya daya beli masyarakat juga merupakan salah satu faktor penting atas berkurangnya permintaan atas daging ayam dan telur, sebagai akibat dari turunnya pendapatan mereka. Selain itu, pada saat penelitian ini dilakukan masih banyak konsumen (masyarakat) yang masih takut ke pasar tradisional untuk berbelanja. Oleh karena itu, permintaan atas daging ayam dan telur di era new normal belum stabil seperti sediakala di saat sebelum terjadi COVID-19. Meskipun demikian, hasil penelitian ini tetap mendukung diterapkannya new normal selama pandemi COVID-19 ini, dibanding pemberlakukan PSBB. Mengingat, penerapan new normal masih memungkinkan usaha pengelolahan daging ayam dan telur beroperasi, sebagai akibat dari pelonggaran kegiatan sosial masyarakat, dan terpenting transaksi jual beli di pasar tradisional dapat terlaksana sebagaimana biasanya, namun tetap memenuhi protokol kesehatan COVID-19. Sehingga, kondisi ini dapat menunjang eksistensi pelaku usaha di pasar tradisional.

Temuan penelitian ini, sejalan dengan Pakpahan (2020) yang menginformasikan bahwa pandemi COVID-19 berimplikasi negatif bagi perekonomian domestik, yakni tercermin dari 
turunnya konsumsi dan daya beli masyarakat, terjadi penurunan kinerja perusahaan. Selain itu, Pakpahan (2020) juga menemukan bahwa pandemi COVID-19 mengancam sektor perbankan dan keuangan, dan eksistensi UMKM. Kemudian, hasil penelitian ini juga mendukung Hardilawati (2020) yang menunjukkan bahwa selama pandemi COVID-19 rerata UMKM mengalami penurunan omzet penjualan. Begitupula, penelitian Sugiri (2020) yang menyimpulkan bahwa pandemi COVID-19 berdampak pada sektor UMKM di Indonesia. Dampak tersebut tercermin dari penurunan penjualan, kesulitan permodalan, terjadi hambatan distribusi produk, serta kesulitan memperoleh bahan baku. Soetjipto (2020) melalui hasil kajiannya, juga menemukan bahwa mayoritas pelaku usaha di sektor UMKM di Jawa Timur selama pandemi COVID-19 ini, mengalami penurunan omzet penjualan yang sangat drastis, menghadapi berbagai kendala pemasaran dan penjualan, dan distribusi produk. Yuliana (2020) juga memperlihatkan bahwa selama pandemi COVID-19, khusunya implementasi kebijakan PSBB diidentifikasi merupakan permasalahan utama turunnya penjualan yang berimplikasi pada pemberhentian operasional perusahaan. Kemudian, Yuliana (2020) juga menemukan bahwa kondisi pandemi ini menyebabkan berkurangnya ketersedian bahan baku, terjadinya penurunan permintaan, dan efek panic buying yang turut berimplikasi pada terhentinya operasional perusahaan.

Di dalam laman Kemenkop-UKM (2020) disebutkan bahwa pemerintah telah menetapkan lima skema perlindungan dan pemulihan koperasi dan UMKM di tengah pandemi COVID-19 yaitu: melalui pemberian bantuan sosial kepada pelaku usaha sektor UMKM yang miskin dan rentan; insentif pajak bagi UMKM; relaksasi dan restrukturisasi kredit bagi UMKM; (d) perluasan pembiayaan modal kerja UMKM; menempatkan kementerian, BUMN dan Pemerintah Daerah sebagai penyangga produk UMKM; pelatihan secara e-learning. Selain itu, Menurut Hadi \& Supardi (2020) yang harus diambil oleh pemerintah dalam rangka mempertahankan eksistensi pelaku usaha (UMKM) di tengah pandemi COVID-19 yaitu perlunya penerapan kebijakan revitalisasi umkm dengan meningkatkan sinergi antar program dan antar lembaga pemerintah, kemudian mengintesifkan promosi produk UMKM di pasar domestik dan ekspor, implementasi kebijakan kredit dengan proses yang sederhana dan suku bunga rendah, terahkir berupaya mondorong peningkatan sarana pendukung UMKM dan kreativitas UMKM sehingga dapat berdaya saing tinggi.

Sementara itu, Sugiri (2020) mengusulkan beberapa strategi tambahan yang dapat diambil sebagai pelengkap kebijakan pemberdayaan UMKM terdampak pandemi COVID-19. Strategi pelengkap tersebut dibagi dua yaitu strategi jangka pendek dan strategi jangka panjang. Strategi jangka pendek melalui penerapan protokol kesehatan yang ketat, pemberian peluang dan dorongan layanan digital, sosialisasi kepada asosiasi dan pelaku usaha, penyederhanaan proses administrasi, dan berupaya mendukung perubahan strategi bisnis. 
Untuk strategi jangka panjang dilakukan melalui upaya penyiapan peta jalan pengembangan UMKM, mengembangkan teknologi digital sebagai platform dalam proses bisnis UMKM, pengembangan model bisnis UMKM yang modern, dan mengupayakan terwujudnya kolaborasi pemerintah dengan korporasi dalam memberdayakan UMKM. Kemudian, Thaha (2020) merekomendasikan kepada pemerintah dalam upaya melindungi kemerosotan UMKM di tengah pandemi COVID-19. Melalui kebijakan jangka pendek pemerintah harus fokus pada pengurangan penambahan korban jiwa COVID-19 dengan penekanan pada stimulus sektor kesehatan dan bantuan kesejahteraan bagi rakyat yang terdampak. Untuk kebijakan jangka menengah, pemerintah memastikan dunia usaha untuk langsung beroperasi, menjaga kesinambungan sektor logistik, dan mendorong kemandirian industri alat kesehatan. Sedangkan strategi jangka panjang, pemerintah harus memfokuskan pada pengenalan dan penggunaan teknologi digital bagi UMKM.

Di sisi lain, Soetjipto (2020) merekomendasi kepada pelaku usaha untuk mengupayakan alternative pemasaran dan penjualan, kemudian fokus mengamankan modal dan aset, untuk sementara beralih ke usaha lainnya yang sesuai dengan kebutuhan saat ini, dan berupaya mempelajari teknologi yang dipandang efektif dalam melakukan promosi dan penjualan. Kemudian, Soetjipto (2020) juga menyarankan kepada pemerintah dalam rangka mempertahankan eksistensi umkm ditengah pandemi COVID-19 yaitu dengan memberikan bantuan operasional berupa rekomendasi keringanan keterlambatan pembayaran, dan membantu pelaku usaha dalam memasarkan dan menyalurkan produk. Selanjutnya, menurut Pratiwi (2020) yang terpenting untuk meringankan beban UMKM di masa pandemi COVID-19 ini adalah bantuan kelonggaran kredit. Hardilawati (2020) berdasarkan hasil penelitiannya, merekomendasi strategi bertahan untuk UMKM berupa melakukan perdagangan secara ecommerce, melakukan pemasaran secara digital, melakukan perbaikan kualitas produk dan penambahan layanan serta menjalin dan mengoptimalkan hubungan pemasaran pelanggan. Sementara menurut Fadly \& Sutama (2020) strategi pemasaran yang sangat efektif yang harus diambil oleh pelaku usaha di masa pandemi ini yaitu dengan melakukan pemasaran online maupun digital branding.

\section{Kesimpulan}

Penelitian ini membahas dampak pandemi COVID-19 terhadap eksistensi pelaku usaha di pasar tradisional. Dalam konteks penelitian ini diukur dengan melihat laba, omzet penjualan, dan jumlah pembeli yang diterima oleh pedagang ayam dan telur di Pasar Sentral Manonda Palu. Hasil penelitian menunjukkan bahwa terdapat perbedaan laba, omzet penjualan, dan jumlah pembeli yang diterima pelaku usaha yang signifikan sebelum dan selama pandemi 
COVID-19. Artinya, pandemi COVID-19 ini mengancam eksistensi pelaku usaha di pasar tradisional. Utamanya, pada saat pemberlakuan PSBB oleh pemerintah. Oleh karena itu, penelitian ini mendukung kebijakan pemerintah tentang penerapan new normal di tengah pandemi COVID-19 ini, karena kebijakan ini dapat menunjang eksistensi pelaku usaha di pasar tradisional. Oleh karena itu, diharapkan kepada para pelaku usaha untuk terus meningkatkan usahanya dengan tetap mematuhi protokol kesehatan dan menjaga kebersihan selama pandemi COVID-19. Penelitian ini terbatas dilakukan pada satu jenis usaha, penelitian selajutnya dapat mengambil jenis usaha yang berbeda dengan jumlah responden yang lebih banyak, dan memperluas lokasi penelitian, tidak pada satu lokasi pasar tradisional saja, bisa juga pelaku UMKM secara keseluruhan.

\section{Daftar Pustaka}

Amri, A. (2020). Dampak Covid-19 Terhadap UMKM di Indonesia. Jurnal Brand, 2(1), 123-130. https://www.academia.edu/42672824/Dampak_Covid-19_Terhadap_UMKM_di_Indonesia

BBC News Indonesia. (2020). Virus corona: Kasus positif Covid-19 ditemukan di pasar tradisional berbagai kota, tapi Kemendag harap pasar tetap dibuka. Retrieved from BBC.COM website: https://www.bbc.com/indonesia/indonesia-52534928

Dito, A. N. D., Erlina, \& Muda, I. (2020). Dampak Pandemi Covid-19 Terhadap Perekonomian Indonesia. Jurnal Benefita, 5(2), 212-224. Retrieved from http://ejournal.Ildikti10.id/index.php/benefita/article/view/5313

Fadli, R. (2020). Coronavirus. Retrieved June 24, 2020, from halodoc.com website: https://www.halodoc.com/kesehatan/coronavirus

Fadly, H. D., \& Sutama. (2020). Membangun pemasaran online dan digital branding ditengah pandemi covid-19. Jurnal Ecoment Global: Kajian Bisnis Dan Management, 5, 213-222. Retrieved from http://ejournal.uigm.ac.id/index.php/EG/article/view/1042

Hadi, S., \& Supardi, S. (2020). Revitalization Strategy for Small and Medium Enterprises after Corona Virus Disease Pandemic (Covid-19) in Yogyakarta. Journal of Xi'an University of Architecture \& Technology, XII(IV). https://doi.org/10.37896/jxat12.04/1149

Hardilawati, W. laura. (2020). Strategi Bertahan UMKM di Tengah Pandemi Covid-19. Jurnal Akuntansi Dan Ekonomika, 10(1), 89-98. https://doi.org/10.37859/jae.v10i1.1934

Junaedi, D., \& Salistia, F. (2020). Dampak Pandemi Covid-19 Terhadap Pasar Modal Di Indonesia: Studi Kasus Indeks Saham Komposit (ISHG). Al-Kharaj: Jurnal Ekonomi, Keuangan \& Bisnis Syariah, 2(2), 109-138. https://doi.org/10.47467/alkharaj.v2i2.112 Kemenkop-UKM. (2020). Menkop dan UKM Paparkan Skema Pemulihan Ekonomi KUMKM Di Masa dan Pasca Covid-19. Retrieved January 14, 2021, from Kementrian Koperasi dan Usaha Kecil dan Menengah Republik Indonesia website: 
http://www.depkop.go.id/read/menkop-dan-ukm-paparkan-skema-pemulihan-ekonomikumkm-di-masa-dan-pasca-covid-19

Pakpahan, A. K. (2020). Covid-19 Dan Implikasi Bagi Usaha Mikro, Kecil, Dan Menengah. Jurnal Hubungan Internasional, O(0), 59-64. https://doi.org/10.26593/jihi.v0i0.3870.59-64

Pratiwi, M. I. (2020). Dampak Covid-19 terhadap perlambatan ekonomi sektor umkm. Jurnal Ners, 4(2), 30-39. Retrieved from http://journal.universitaspahlawan.ac.id/index.php/ners Republik Indonesia. (2007). Peraturan Presiden (PERPRES) Nomor 112 Tahun 2007 Tentang Penataan dan Pembinaan Pasar Tradisional, Pusat Perbelanjaan dan Toko Modern. Jakarta: Sekretariat Negara.

Rosita, R. (2020). Pengaruh Pandemi Covid-19 Terhadap Umkm Di Indonesia. Jurnal Lentera Bisnis, 9(2), 109. https://doi.org/10.34127/jrlab.v9i2.380

Saraswati. (2020). Dampak Pandemi Covid-19 Terhadap Pasar Modal Di Indonesia. Jurnal Riset Akuntansi \& Keuangan Dewantara, 3(2), 153-163. https://doi.org/10.47467/alkharaj.v2i4.112

Setiawan, R. (2020). Update Corona Indonesia, 31 Desember 2020: 194 Jiwa Meninggal Dunia. Retrieved January 10, 2021, from tirto.id website: https://tirto.id/update-corona-indonesia31-desember-2020-194-jiwa-meninggal-dunia-f8Hg.\%09

Soetjipto, N. (2020). Ketahanan UMKM Jawa Timur Melintasi Pandemi COVID-19. Retrieved from http://repository.stieyapan.ac.id/id/eprint/73/1/Ketahanan UMKM Jawa Timur melintasi Pandemi Covid 19_HM. Noer Soetjipto.pdf

Sugiri, D. (2020). Menyelamatkan Usaha Mikro, Kecil dan Menengah dari Dampak Pandemi Covid-19. Fokus Bisnis: Media Pengkajian Manajemen Dan Akuntansi, 19(1), 76-86. https://doi.org/10.32639/fokusbisnis.v19i1.575

Thaha, A. F. (2020). Dampak Covid-19 Terhadap UMKM di Indonesia. Jurnal Brand, 2(1), 147153. Retrieved from https://ejournals.umma.ac.id/index.php/brand\%0Ae-ISSN

Utama, A. (2003). Virus baru : Coronavirus dan Penyakit SARS. Retrieved June 23, 2020, from Lembaga IImu Pengetahuan Indonesia website: http://lipi.go.id/berita/virus-baru-:coronavirus-dan-penyakit-sars/176

Wibawa, H., Priyagus, P., \& Gaffar, E. U. A. (2018). Perbedaan omzet dan jam kerja ritel tradisional. Forum Ekonomi, 20(1), 25. https://doi.org/10.29264/jfor.v20i1.3310

Wyati, S., Ariefiantoro, T., \& Santoso, A. (2011). Analisis dampak usaha ritel modern terhadap usaha ritel tradisional (studi kasus di wilayah kecamatan gunungpati, mijen, tembalang, dan banyumanik). Riptek, 5(I), 31-43. Retrieved from https://docplayer.info/40180477Analisis-dampak-usaha-ritel-modern-terhadap-usaha-ritel-tradisional-studi-kasus-diwilayah-kecamatan-gunungpati-mijen-tembalang-dan-banyumanik.html

Yuliana, L. (2020). Dampak Kondisi Pandemi di Indonesia Terhadap Trend Penjualan (Studi 
Kasus pada PD. Sumber Jaya Aluminium). JRB-Jurnal Riset Bisnis, 4(April), 27-38. Retrieved from http://journal.univpancasila.ac.id/index.php/jrb/\%0ADAMPAK 
Lampiran:

\section{KUESIONER PENELITIAN}

PANDEMI COVID-19: DAMPAKNYA PADA EKSISTENSI PELAKU USAHA DI PASAR TRADISIONAL

\section{A. Karakteristik Responden}
1. Nama
2. Umur
3. Jenis Kelamin
4. Nomor Telp/Hp
5. Pengalaman Berdagang
: Laki-Laki / Perempuan
tahun

B. Eksistensi Pelaku Usaha Sebelum dan Selama Pandemi COVID-19

Berapa rata-rata laba (keuntungan), omzet penjualan dan jumlah pembeli perbulan pada tempat bapak/ibu?

\begin{tabular}{|c|l|l|c|c|}
\hline \multirow{2}{*}{ No } & Eksistensi Pelaku Usaha & \multirow{2}{*}{$\begin{array}{c}\text { Sebelum } \\
\text { Covid-19 } \\
\text { (Sebelum Maret) }\end{array}$} & $\begin{array}{c}\text { PSBB } \\
\text { (April, Mei, \& } \\
\text { Juni) }\end{array}$ & $\begin{array}{c}\text { New Normal } \\
\text { (Juli, Agustus, \& } \\
\text { September) }\end{array}$ \\
\hline 1 & Laba (Rupiah) & & & \\
\hline 2 & Penjualan (Rupiah) & & & \\
\hline 3 & Jumlah Pembeli (Orang) & & & \\
\hline
\end{tabular}

C. Saat adanya penerapan PSBB di Kota Palu pada bulan April, Mei dan Juni

Apakah anda merasakan ada perubahan terhadap rerata laba (keuntungan), omzet penjualan dan jumlah pembeli perbulan pada tempat anda?

\begin{tabular}{|l|c|c|c|}
\hline \multirow{2}{*}{ Variabel } & \multicolumn{2}{c|}{ Ya } & \multirow{2}{*}{ Tidak } \\
\cline { 2 - 3 } & Naik (\%) & Turun (\%) & \\
\hline Laba & & & \\
\hline Penjualan & & & \\
\hline Jumlah Pembeli & & & \\
\hline
\end{tabular}

D. Saat Penerapan New Normal di Kota Palu pada bulan Juli, Agustus, dan September : Apakah anda merasakan ada perubahan terhadap rerata laba (keuntungan), omzet penjualan dan jumlah pembeli perbulan pada tempat bapak/ibu ?

\begin{tabular}{|l|l|l|l|}
\hline \multirow{2}{*}{ Variabel } & \multicolumn{2}{|c|}{ Ya } & \multirow{2}{*}{ Tidak } \\
\cline { 2 - 4 } & Naik (\%) & Turun (\%) & \\
\hline Laba & & & \\
\cline { 2 - 4 } Jenjualan & & & \\
\cline { 2 - 4 } & & & \\
\hline
\end{tabular}

